\title{
THE IMAGE OF FINANCIAL INSTITUTION AS ISLAMIC BANK IN MEDIATION SERVICE QUALITY AND CUSTOMER SATISFACTION ON CUSTOMER LOYALTY IN PURWOKERTO
}

\author{
Chandra Warsito ${ }^{1}$
}

\begin{abstract}
The Image of Financial Institution as Islamic Bank In Mediation Service Quality and Customer Satisfaction on Customer Loyalty in Purwokerto. The paper aims to determine the effect of service quality on customer satisfaction, service quality, customer satisfaction and image on customer loyalty, quality of service to the company's image, to determine the image of financial institutions in mediating the relationship variable quality of service and customer satisfaction on customer loyalty. The samples used were 110 customers and methods of analysis used is Structural Equation Modeling (SEM) test results find no significant effect of service quality on customer satisfaction; quality of service loyalty; customer satisfaction on customer loyalty; quality of service to the image of the company; customer satisfaction with the company's image; and the image of the company loyalty; Image of financial institutions PT. BPRS BAS can be used as a variable relationship mediation variable service quality and customer satisfaction on customer loyalty.
\end{abstract}

Keywords: Image of financial institutions, satisfaction, quality of service, loyalty.

\begin{abstract}
Abstrak. Gambaran Lembaga Keuangan Sebagai Bank Syariah Terhadap Kualitas Layanan dan Kepuasan Konsumen Pada Loyalitas Konsumen di Purwokerto. Artikel ini bertujuan untuk mengetahui pengaruh kualitas pelayanan terhadap kepuasan nasabah, kualitas pelayanan, kepuasan nasabah dan citra terhadap loyalitas nasabah, kualitas pelayanan terhadap citra perusahaan, serta untuk mengetahui citra lembaga keuangan dalam memediasi hubungan variabel kualitas pelayanan dan kepuasan nasabah terhadap loyalitas nasabah. Sampel yang digunakan adalah 110 nasabah dan metode analisis yang digunakan adalah Structural Equation Modelling (SEM). Hasil pengujian menemukan ada pengaruh signifikan dari kualitas pelayanan terhadap kepuasan konsumen; kualitas pelayanan terhadap loyalitas; kepuasan konsumen terhadap loyalitas konsumen; kualitas pelayanan terhadap terhadap citra perusahaan; kepuasan konsumen terhadap citra perusahaan; dan citra perusahaan terhadap loyalitas; Citra lembaga keuangan PT. BPRS BAS dapat digunakan sebagai variabel pemediasi hubungan variabel kualitas pelayanan dan kepuasan nasabah terhadap loyalitas nasabah.
\end{abstract}

Kata Kunci: gambaran lembaga keuangan, kepuasan, kualitas layanan, loyalitas

First draft: February, $3^{\text {rd }}$ 2015, Revision: March, 10 ${ }^{\text {th }}$ 2015, Accepted: April, $2^{\text {nd }} 2015$

1 IAIN Purwokerto. Jl. Jenderal Ahmad Yani, Purwokerto, Central Java, Indonesia

Email: warsitochandra@yahoo.co.id 


\section{Introduction}

High competition in the banking industry is not directly force the banking company to adjust with the phenomena occurring in the community. To be able to win the competition, the banking industry is currently vying to improve service to its customers, all of which are intended to increase customer satisfaction. Every banking company is required to deliver maximum performance to customers, because of the positive or negative a service company is highly dependent on the assessment of the community to get such services. The better the service provided is of a bank, the higher the likelihood of the trust of customers to obtain services that are offered, which in turn is able to realize customer loyalty.

The image of the company is one of the factors used to build customer loyalty. The image is a reality in which the program development and improvement of the image based on the fact. If the image does not correspond with reality and good performance then it is an error in Communication Company. A good image is indicative of the company's success in providing services capable of satisfying its customers (Arafah, 2004).

Efforts to establish the company in the long term can also be done by increasing customer satisfaction. Customer satisfaction can be achieved if the company is able to realize the expectations of customers. The achievement of the expectations on the customer will give effect customers to stay afloat and not move to another company. Especially on emotionally, customers have a special affinity with the personnel in the company, it will facilitate relations between companies and customers. The relationship with the customer will make a customer more loyal to the company.

The high customer interest in a variety of Islamic banking transactions led idea in the banking business people to establish BPR of Sharia and one that stands in Purwokerto is PT. BPRS BAS (Bina Amanah Satria). In its activities, PT. BPRS BAS (Bina Amanah Satria) operates sharia. There are Islamic financial institutions in Purwokerto, providing a wide range of alternative transactions, all of which is done by sharia. For that, PT. BPRS BAS (Bina Amanah Satria) need to create the image that customers easily identify and easy to remember if society requires banking transactions. The existence of image appearance on banking company raises an open competition between banks.

High competition in the Islamic banking business, making companies need to prepare themselves with better service to make customers feel satisfied with the services provided. Enhancing the quality of service was done to the satisfaction of customers so that customers remain loyal with company.

Quality of care is influenced by two factors, namely the expected service and 
perceived service (Tjiptono, 2001). Suitability of service received by customers in the hope, perceived good and satisfactory, if the ideal is said to exceed customer expectations, and vice versa if the received lower than expected will be badly perceived by customers (Kotler, 1999). Zeithaml, et all, (in Tjiptono, 2001) states that the customer expectation is customer confidence before buying a product which that used as a standard in assessing the performance of product.

Services can be given a firm, if the customer comes transaction. And transactions can occur if the customer comes and want to take advantage of all the financial services offered. For this reason, companies need to instill a good image in the minds of customers so that they would come and perform transactions with the company.

Image is an important part of marketing management, where the image is built and associated with a habit, lifestyle, benefits, product attributes, geography, price, competitors, celebrities and others (Durianto, 2001). The strength of company's image is very important to be maintained and improved, with the purpose of attracting the hearts of borrowers and customers, so the debtor and customers are satisfied with the services of the company.

PT. BPRS BAS (Bina Amanah Satria) as one of the sharia institution, always strive to provide the best service to borrowers and customers, with the goal of giving satisfaction with the services provided. Satisfaction is the perception of one's feelings after comparing the performance with expectations (Kotler, in Tjiptono, 2000). Satisfaction or dissatisfaction of customers occurs after an evaluation of the expectations of customers prior to the actual performance that is felt after use (Tse and Wilton in Tjiptono, 2001).

It is important to be achieved by the service company, is the satisfaction both by customers and debtors. The problem that arises is, all companies raced to give satisfaction to customers and debtors. Each company sets the strategy and policy to build relationships with customers. Various attempts were made so that the company can interact with clients and debtors investigate and analyze their needs, using technology, to improve service and sales (Maryono, 2007).

\section{Literature Review}

Customer loyalty is important for any company, because loyalty reflects the positive perception of customer against the company. Loyalty is the attitude shown in determining the choice of customers continues to use the products or services offered by the company. Attitude determines the attitude, led commitment of customers to re-purchase or obtain the services offered on the company (Foster 
and Cadogan, 2000). Thus the meaning of loyalty is loyalty of customers to make repeat purchases over the same services from one company and attitude would tell the others and be a deterrent from many competitors who entered. It also shows the loyalty of customers is a factor that determines the success of the company.

Quality of service is an effort to fulfill the needs and desires of customers and determination to deliver and offset expectations of customers (Tjiptono, 2000). There are two main factors that affect the quality of the service; the expected service and perceived service (Parasuraman, in Tjiptono, 2000). If the perceived service as expected, then the perceived service quality is good and satisfying. If the services received exceed customer expectations, then the quality of service perceived as the ideal quality. Conversely, if the services received is lower than what is expected, then the perceived poor quality of services.

Customer satisfaction is defined as a decision on the basis of a specific services meeting (Bolton and, 1991; Cronin and Taylor, 1992 in Nha Nguyen and Gaston LeBlanc, 1998). This is in accordance with the opinion of Oliver'S (1981 Nha Nguyen and Gaston LeBlanc, 1998) which looked at satisfaction as an emotional reaction that affects attitudes. Based on this perspective, Cronin and Taylor (1994 in Nha Nguyen and Gaston LeBlanc, 1998) say that customer satisfaction should be limited to the quality of services and transaction decisions specific to long-term attitude, resulting in a cumulative effect that the satisfaction of services should be directed to the evaluation of the quality of services global from time to time (Parasuraman et al., 1994 in Nha Nguyen and Gaston LeBlanc, 1998). Of the opinions mentioned above, according to the researchers, satisfaction was preceded by the quality of services (Bolton and, 1991 in Nha Nguyen and Gaston LeBlanc, 1998).

Teh (1993) in Nha Nguyen and Gaston LeBlanc, 1998) in his research concluded that quality and customer satisfaction, both tested based on a global perspective that specific transaction. Evaluation of satisfaction associated with the value (Zeithaml, 1988 in Nha Nguyen and Gaston LeBlanc, 1998), re-purchase (Oliver and Goose, 1989 in Nha Nguyen and Gaston LeBlanc, 1998), as well as customer loyalty towards the company (Kasper, 1988 in Nha Nguyen and Gaston LeBlanc, 1998). Fornell (1992) in Nha Nguyen and Gaston LeBlanc, 1998), in his study that while the quality and customer satisfaction are important for all companies, but the satisfaction becomes even more important because it will give the faithful, especially in companies such as banks, insurance, orders per post, and transportation. Satisfaction and customer dissatisfaction is the customer response to the discrepancy evaluation/ perceived disconfirmation between prior expectations (or other performance norms) and the actual performance of the product that is felt 
after use (Tjiptono, 2005).

Many corporate image definition found in the literature of psychology and marketing. Image has been described from the knowledge of the relationship (Boulding, 1956 in Nha Nguyen and Gaston LeBlanc, 1998); the image is an attitude (Hirschman et al., 1978 in Nha Nguyen and Gaston LeBlanc, 1998), and a combination of product characteristics from a product known (Erickson et al., 1984 in Nha Nguyen and Gaston LeBlanc, 1998).

Imagery is the overall impression left on the mind of customer (Zimmer and Golden, 1988 in Nha Nguyen and Gaston LeBlanc, 1998). Various factors inherent in the image are tradition, ideology, company name, reputation, price levels, variations in services, and the quality that communicated by every person who interacts with a service company. Another aspect of the image forming is corporate identity, quality and level of advertising and the delivery system also serves to build the image. The image is a procedure that associated with the ideas, feelings and previous experience with an organization that stored in memory and transformed into a sense based on the category (McInnis and Price (1987) in Nha Nguyen and Gaston LeBlanc, 1998), with Yuille and Catchpole (1977 in Nha Nguyen and Gaston LeBlanc, 1998).

Two main components of image are known by emotionally and functionally (Kennedy, 1977 in Nha Nguyen and Gaston LeBlanc, 1998). Functional components associated with cues that can be measured easily, being the emotional component associated with psychological stated with feeling and attitude. To form the image in minds of customers, the company did it through a particular symbol, where it is able to demonstrate a certain image. In the form of customer, the image is described as being stored in memory from the general impression through the evaluation of highly detailed objects associated with personal values.

Results of research conducted by Nha Nguyen and Gaston LeBlanc (1998) concluded that service quality positively and significantly related to customer satisfaction. Research conducted by Wong and Sohal (2003) also concluded that the quality of services directly influence the trust and loyalty of customers. Research on quality of service with loyalty conducted by Bloemer et al (1998) concluded that there are significant of quality perception to the satisfaction.

Satisfaction is the result of a customer overall evaluation to the product or services obtained after comparison with similar products from competing companies, where there is a match between performance and expectations. Research conducted by Ball et al (2006) on service and customer loyalty. From this study, it can be seen that the quality of service is not directly affect the loyalty through customer 
satisfaction. Nha Nguyen and Gaston LeBlanc (1998) concluded that customer satisfaction has a positive and significant effect on loyalty.

Jay Kandampully and Dwi Suhartanto (2000) concluded that customer satisfaction with the reception, food and beverage, and price has no effect on customer loyalty. While Ball et al (2004) in his study found that the image has an effect on loyalty and customer satisfaction, perceived value affects customer satisfaction. While the research conducted by Nha Nguyen and Gaston LeBlanc (1998) concluded that the image of company has a positive and significant effect on loyalty.

Increased customer satisfaction can be done by improving the image of company. The company will have a strong image if customers believe that they are the higher value when they transact with the company (Bloemer at al (1998)). Research conducted by Brunner et al (in Bloemer at al (1998)) conclude that the image effect on customer satisfaction. Bloemer et al (1998) in his study conclude that there is a significant positive relationship between the variables studied, namely Image, Service Quality and Satisfaction. This shows that satisfaction is influenced by many factors, including customer satisfaction and corporate image. Research conducted by Caruana (2002) concluded that service quality affects customer satisfaction but has no effect on customer loyalty. From the above, it is known that the quality of service also has a very important role in influencing loyalty, in addition to variables of customer satisfaction and corporate image.

\section{Methods}

This study is conducted on customers of PT. BPRS BAS Purwokerto. The sample size is adjusted by the method of analysis, namely Structural Equation Modeling (SEM) which is five times the number of items of research (Ferdinand, 2005). In this study there are 19 items, so that the minimum sample size is 95 respondents. Under these provisions, the sampling method used is simple random sampling, which took some part of the population sampled randomly for the study, namely all the customers who are customers of PT. BPRS BAS Purwokerto.

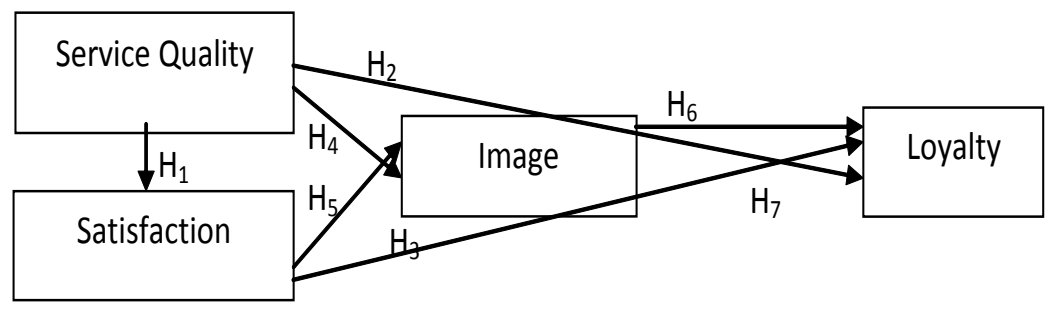

Figure 1. The Research Model 
The Hypothesis on this research are below:

$\mathrm{H}_{1}$ : Service quality has a significant influence on customer satisfaction

$\mathrm{H}_{2}$ : The quality of service has a significant influence on customer loyalty

$\mathrm{H}_{3}$ : Customer satisfaction has a significant influence on customer loyalty

$\mathrm{H}_{4}$ : The quality of service affects the image of the company

$\mathrm{H}_{5}$ : Customer satisfaction affects the company's image

$\mathrm{H}_{6}$ : Corporate image effect on loyalty

$\mathrm{H}_{7}$ : The image of the financial institution PT. BPRS BAS mediates the relationship variable of service quality and customer satisfaction on customer loyalty

\section{Discussion}

Fitness Model Tests conducted by The goodness of fit criteria include goodness of fit : Chi -Square, probability, RMSEA, Cmin / DF, GFI, AGFI, TLI, CFI and DF. The results of test calculations FITNESS statistical model can be seen in Table 1 below.

Table 1. Feasibility Index testing the structural equation modeling model

\begin{tabular}{lccc}
\hline \multicolumn{1}{c}{ Goodness of fit index } & $\begin{array}{c}\text { Cut-of } \\
\text { value }\end{array}$ & Result & Model evaluation \\
\hline c $^{2}$-Chi-square & 174,907 & 188,666 & Good \\
Significancy probability & $\geq 0.05$ & 0,052 & Good \\
RMSEA & $\leq 0.08$ & 0,043 & Good \\
GFI & $\geq 0.90$ & 0,859 & Marginal \\
AGFI & $\geq 0.90$ & 0,816 & Marginal \\
CMIN/DF & $\leq 2.00$ & 1,198 & Good \\
TLI & $\geq 0.95$ & 0,976 & Good \\
CFI & $\geq 0.95$ & 0,972 & Good \\
\hline
\end{tabular}

One of the test equipment to measure the overall fit is the likelihood ratio chi-square statistic. The model was tested to be considered good or satisfactory when Chi - Square value is low. The smaller the value the better the Chi - Square and the model was accepted by the probability of the cut of the value of $\mathrm{P}>0.05$ (Hulland in Ferdinand , 2000) . In this study, Chi - Square value obtained is equal to 188.666 with a value of $p=0.052$. It can be concluded that the model in this study include a good model or structural models generated showed the best model .

The Root Mean Square Error Of Approximation (RMSEA) values less than or equal to 0.08 is an index to the acceptability of the model showed a close fit of the model was based on the degress of Freedoom (Brown \& Cudeck in Ferdinand, 2000). Based on this study RMSEA value obtained is equal to 0.043 . Thus, it 
includes a very good fit because its RMSEA values less than 0.08 . Goodness of Fit Index (GFI) value generated in this study was 0.859 . This value is smaller than 0.90 so including marginal figure. Next, we try to examine the Adjusted Goodness of Fit Index (AGFI). Recommended level of acceptance is when AGFI has a value equal to or greater than 0.90 . AGFI's value generated in this study is 0.816 . This value is smaller than 0.90 so including marginal.

Tucker Lewis Index (TLI) is an alternative incremental fit index which compares a model that is tested against a baseline model (Baumgartner and Homburg, 1996) in Ferdinand, 2000). Value is very close to 1 or more than 0.95 indicates a very good fit (Arbuckle, 1997) in Ferdinand, 2000; 57). TLI values generated in this study was 0,972. Comparative Fit Index (CFI), the magnitude of this index is in the range of values of 0 (poor fit) up to 1.0 (perfect fit). Value greater or equal to 0.95 indicates the highest level of fit a very good fit (Arbuckle, 1997 in Ferdinand, 2000). CFI value generated in this study was 0,972 . This value is greater than 0.95 , thus including a very good fit. The magnitude of the Comparative Fit Index is in the range of values of 0 ( poor fit) up to 1.0 (perfect fit). Value greater or equal to 0.95 indicates the highest level of fit a very good fit (Arbuckle, 1997 in Ferdinand, 2000). CFI value generated in this study was 0,972 . This value is greater than 0.95 , thus including a very good fit.

The results of structural equation modeling analysis processing (SEM) can be seen in Figure 2 and Table 2.

Table 1. Results of structural equation modeling analysis

\begin{tabular}{llllll}
\hline \multicolumn{1}{c}{ Variable 1 } & \multicolumn{1}{c}{ Variable 2 } & Estimate & S.E. & C.R. & P \\
\hline $\begin{array}{l}\text { Customer } \\
\text { satisfaction }\end{array}$ & Service quality & 0.458 & 0.138 & 4.108 & 0,000 \\
Image & Service quality & 0.350 & 0.146 & 3.399 & 0,000 \\
Image & Customer satisfaction & 0.474 & 0.126 & 4.307 & 0,000 \\
Loyalty & Service quality & 0.224 & 0.155 & 2.082 & 0.037 \\
Loyalty & Customer satisfaction & 0.243 & 0.139 & 2.031 & 0.042 \\
Loyalty & Image & 0.359 & 0.135 & 2.706 & 0.007 \\
\hline
\end{tabular}

Based on Table 1 it can be seen the results of the analysis of structural equation modeling (SEM). Value estimate coefficients listed in Table 1 are standardized coefficient or standardized regression coefficient, which is also called path coefficients. In the discussion of the research hypothesis testing used this path coefficients. The value of the standard error, the value of the critical ratio $(\mathrm{CR})$ and the $\mathrm{p}$-value equal between the standardized and unstandardized regression coefficient. 


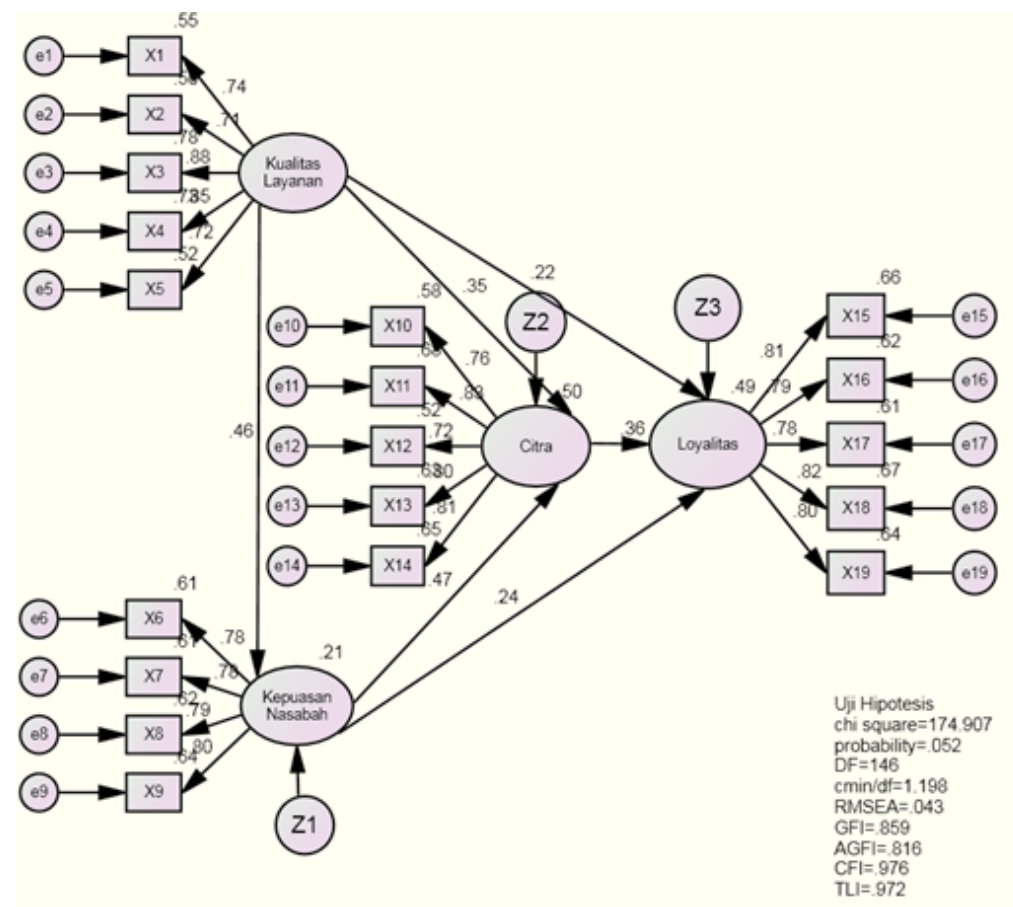

Figure 2. Results of structural equation modeling analysis

Based on Table 1 can be made to the substructure structural equation 1 as follows :

Customer satisfaction $=0.458$ Quality of service $+\mathrm{Z} 1$

Image $=0.350$ Service Quality +0.474 Customer Satisfaction + Z2

Loyalty $=0.224$ Service Quality +0.243 Customer Satisfaction +0.359 image + Z3

Based on the result above, we can explained as: Firts, impact of service quality on customer satisfaction. The estimated value of the variable path coefficient of service quality on customer satisfaction by 0.458 . This indicates variable service quality has a positive effect on customer satisfaction, which is the better quality of service it will result in increased customer satisfaction. Based on the obtained value significance test $\mathrm{p}=0.000$. This means that there is a positive and significant impact on the quality of service to customer satisfaction.

Second, impact of service quality and customer satisfaction to image. The estimated value of the variable path coefficient of service quality to the image of 0.350. This indicates the variable quality of service has a positive influence on the image, better the quality of service it will result in better image. Based on the obtained significance test $p=0.000$. This means that there is a positive and 
significant effect of the variable quality of service to the image. The estimated value of customer satisfaction variables path coefficient of 0.474 on the image. This indicates variable customer satisfaction has a positive influence on the image, ie the better the customer satisfaction will result in better image. Based on the obtained significance test $\mathrm{p}=0.000$. This means that there is a positive and significant impact of customer satisfaction on the image.

Third, impact of service quality, customer satisfaction and loyalty image. The estimated value of the variable path coefficient quality of service to the loyalty of 0.224 . This indicates the variable quality of service has a positive influence on loyalty, ie the better the quality of service it will result in stronger loyalty. Based on the obtained significance test $\mathrm{p}=0.037$. This means that there is a positive and significant impact on the quality of service to loyalty.

The estimated value of the variable path coefficient customer satisfaction to loyalty of 0,243 . This indicates variable customer satisfaction has a positive influence on loyalty, customer satisfaction is the better it will result in stronger loyalty. Based on the obtained significance test $\mathrm{p}=0.042$. This means that there is a positive and significant impact of customer satisfaction on loyalty. The estimated value of the image variable path coefficient of 0.359 loyalty. This shows the image variable has a positive influence on loyalty, ie the better the image will result in stronger loyalty. Based on the obtained significance test $\mathrm{p}=0.007$. This means that there is a positive and significant impact on the image of loyalty.

Fourth, image of financial institutions PT BPR BAS mediates the relationship of ariable quality customer service and satisfaction on customer loyalty. Testing mediation conducted by Sobel test. Sobel test results can be seen in Table e.

Table 3. Test results Sobel

\begin{tabular}{llccl}
\hline No & Variable relationship & T tast & T table & Information \\
\hline 1 & $\begin{array}{l}\text { Service quality- Image- } \\
\text { Loyalty }\end{array}$ & 1.7149 & 1.9822 & No mediation \\
2 & $\begin{array}{l}\text { Customer Satisfaction } \\
\text {-Image - Loyalty }\end{array}$ & 2.1221 & 1.9822 & Mediation \\
\hline
\end{tabular}

According to the table 3 can be known image can not mediate the relationship between the variables of service quality and loyalty. However, variable image can mediate the relationship between the variables of satisfaction and loyalty. This suggests a significant influence indirectly from satisfaction to loyalty through imagery. 


\section{Conclusion}

Based on the results of testing the effect of service quality on customer satisfaction can be concluded that: first, there is a positive and significant effect of the variable quality of service to customer satisfaction. Second, there is a positive and significant effect of the variable quality of service loyalty. Third, there is a positive and significant effect of customer satisfaction on customer loyalty. Fourth, service quality affect the company's image. Fifth, consumer satisfaction influence the corporate image. Sixth, corporate image effect on loyalty.

From this research, customer satisfaction can be improved with everything possible to improve service quality include increasing physical form (tangible), empathy, reliability of service, responsiveness and customer assurance provision for all transactions carried out in Islamic rural bank. Increased loyalty can also be enhanced by improving the satisfaction and fulfillment guarantees satisfaction with the services rendered. The company is expected to meet the wishes of customers, providing overall satisfaction in line with expectations. And to instill a positive image to the customer, the company can do to improve the quality of service for customer satisfaction. Although the image of financial institution PT. BPRS BAS can't be a variable liaison, but it can serve as a liaison customer satisfaction on customer loyalty. This shows that customer satisfaction has a stronger effect in enhancing the image and loyalty compared to quality of service.

\section{References}

Anderson, E.W. et.al. 1994. Customer Satisfaction, Market Share and Profitability: Finding From Sweden. Journal of Marketing, Vol. 58, pp. 101-120.

Andreassen, T. W. 1994. Satisfaction, Loyalty and Reputation as Indicators of Customer Orientation in the Public Sector. International Journal of Public Sector Management, Vol. 7, No.2, pp.16-34.

Andreassen \& Lindestad. 1996. Customer loyalty and complex services: the impact of corporate image on quality, customer satisfaction and loyalty for customers with varying degrees of service expertise. International Journal of Service Industry Management. Vol. 9 No. I 1998, pp. 7-23.

Arafah, W. 2004. Analisis Kualitas Pelayanan Rumah Sakit Terhadap Image (Studi Pada Rumah Sakit "X" di Jakarta Selatan). Media Riset Bisnis dan Manajemen, Vol.4 No.1: 55-75.

Azwar, S. 2000. Validitas dan Reliabilitas. Yogyakarta: Pustaka Pelajar.

Ball, et.al. 2004. The role of communication and trust in explaining customer loyalty: an extension to the ECSI model. European Journal of Marketing Volume 38 Number 9/10 2004, pp. 1272-1293. 
Ball, et.al. 2006. Service personalization and loyalty. Journal of Services Marketing Volume 20 Number 62006 , pp. 391-403

Bloemer, et.al. 1998. Investigating Drivers Of Bank Loyalty: The Complex Relationship Between Image, Service Quality And Satisfaction. International Journal of Bank Marketing 16/7 1998, pp. 276-286

Caruana, A. 2002. The effects of service quality and the mediating role of customer satisfaction. European Journal of Marketing Volume 36 Number 7/8 2002, pp. 811-828

Dimitriades. Z.S 2006. Customer satisfaction, loyalty and commitment in service organizations. Management Research News Volume 29 Number 122006 p. 782-800.

Ferdinand, A. 2000. Manajemen Pemasaran: Sebuab Pendekatan Stratejik. Semarang: Universitas Diponegoro.

Foster, B.D. \& J.Q. Cadogan. 2000. Relationship Selling and Costumer Loyalty: An Empirical Investigation. Marketing Investigation and Planning, 18/4.

Ghozali, I. 2009. Ekonometrika: Teori, Konsep dan Aplikasi dengan SPSS 17.0. Semarang: Badan Penerbit Universitas Diponegoro.

Kandampully, J. \& D.Suhartanto. 2000. Customer loyalty in the hotel industry: the role of customer satisfaction and image. International Journal of Contemporary Hospitality Management Volume 12 Number. 6, 2000, pp. 346-351

Kotler, P. 1999. Manajemen Pemasaran: Analisis, Perencanaan, Implementasi dan Kontrol Jilid Kedua. Jakarta: Prenhallindo.

Mowen, J.C. 1995. Customer Behavior. New Jersey: Prentice Hall.

Nha, Nguyen \& G. Le Blanc. 1998. The mediating role of corporate image on customers' retention decisions: an investigation in financial services. International Journal of Bank Marketing Volume 16 Number 2, 1998, pp. 52-65

Selnes, F. 1993. An Examination the Effect of Product Performance on Brabd Reputation, Satisfaction and Loyalty. European Journal of Marketing, vol. 27, no. 9, pp.19-35.

Sutisna. 2001. Perilaku Konsumen dan Komunikasi Pemasaran. Bandung: Remaja Rosdakarya.

Tjiptono, F. 2005. Strategi Pemasaran. Yogyakarta: Penerbit Andi.

Wong \& Sohal. 2003. Service quality and customer loyalty perspectives on two levels of retail relationships. Journal of Services Marketing Volume 17 Number 5 2003, pp. 495-513

Wong \& Sohal. 2006. Understanding the Quality of Relationships in customer services. A Studi in retail environment. International Journal of Quality \& Reliability Management Vol. 23 No. 3, 2006, pp. 244-264 